\title{
Effect of heat and thermosonication treatments on peroxidase inactivation kinetics in watercress (Nasturtium officinale)
}

\author{
Rui M.S. Cruz ${ }^{\text {a }}$, Margarida C. Vieira ${ }^{b}$, Cristina L.M. Silva ${ }^{a, *}$ \\ ${ }^{a}$ Escola Superior de Biotecnologia, Universidade Católica Portuguesa, Rua Dr. António Bernardino de Almeida, 4200-072 Porto, Portugal \\ ${ }^{\mathrm{b}}$ Escola Superior de Tecnologia, Universidade do Algarve, Campus da Penha, 8005-139 Faro, Portugal
}

Keywords: Watercress (Nasturtium officinale); Heat; Ultrasound; Inactivation; Peroxidase; Kinetics; Modelling

\begin{abstract}
The effect of heat and the combined heat/ultrasound (thermosonication) treatment on the inactivation kinetics of peroxidase in watercress (Nasturtium officinale) was studied in the temperature range of $40-92.5^{\circ} \mathrm{C}$. In the heat blanching processes, the enzyme kinetics showed a first-order biphasic inactivation model. The activation energies and the rates of the reaction at a reference temperature for both the heat-labile and heat-resistant fractions were, respectively, $E_{\mathrm{a} 1}=421 \pm 115 \mathrm{~kJ} \mathrm{~mol}^{-1}$ and $E_{\mathrm{a} 2}=352 \pm$ $81 \mathrm{~kJ} \mathrm{~mol}^{-1}, k_{1846^{\circ} \mathrm{C}}=18 \pm 14 \mathrm{~min}^{-1}$ and $k_{2846^{\circ} \mathrm{C}}=0.24 \pm 0.14 \mathrm{~min}^{-1}$. The initial relative specific activity for both isoenzyme fractions were also estimated, being $C_{01}=0.5 \pm 0.08 \mu \mathrm{mol} \mathrm{min}^{-1} \mathrm{mg} \mathrm{protein}^{-1}$ and $C_{02}=0.5 \pm 0.06 \mu \mathrm{mol} \mathrm{min}^{-1} \mathrm{mg}$ protein ${ }^{-1}$, respectively. The application of thermosonication was studied to enable less severe thermal treatments and, therefore, improving the quality of the blanched product. In this treatment the enzyme kinetics showed a first-order model. The activation energy, the rate of reaction at a reference temperature and the initial relative specific activity were, respectively, $E_{\mathrm{a} 3}=496 \pm 65 \mathrm{~kJ} \mathrm{~mol}^{-1}, k_{37.55^{\circ} \mathrm{C}}=10 \pm 2 \mathrm{~min}^{-1}$ and $C_{03}=1 \pm 0.05 \mu \mathrm{molmin}^{-1} \mathrm{mg}$ protein ${ }^{-1}$, proving that the enzyme became more heat labile. The present findings will help to design the blanching conditions for the production of a new and healthy frozen product, watercress (Nasturtium officinale), with minimized colour or flavour changes along its shelf life.
\end{abstract}

\section{Introduction}

Watercress (Nasturtium officinale) is a hardy perennial European herb of the family Cruciferae (mustard family) that grows in and around water. Normally, it is commercialised in fresh and consumed in salads, soups and other recipes. It is considered an excellent functional food for the prevention of cancer and related

\footnotetext{
* Corresponding author. Tel.: +35122558 0058; fax: +35122509 0351.

E-mail addresses: rcruz@ualg.pt (R.M.S. Cruz), mvieira@ualg.pt (M.C. Vieira), clsilva@esb.ucp.pt (C.L.M. Silva).
}

diseases. Its short shelf life, of nearly seven days, can be extended through freezing, allowing a longer period for distribution and storage. However, when frozen, care must be taken with the enzyme peroxidase activity.

Peroxidase (POD) is an enzyme commonly found in vegetables and it is a heme-containing enzyme, which can catalyse a large number of reactions in which a peroxide is reduced while an electron donor is oxidized, and it is considered to have an empirical relationship to offflavours and off-colours in raw and unblanched frozen vegetables (López et al., 1994). Therefore, the inactivation of this enzyme increases the shelf life of vegetables during frozen storage and is often used as an index for blanching adequacy (Barret \& Theerakulkait, 1995; Williams, Lim, Chen, Pangborn, \& Whitaker, 1986). 


\section{Nomenclature}

C specific activity, or relative specific activity

2 relative to resistant enzyme fraction

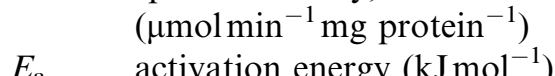

$k \quad$ rate of reaction $\left(\mathrm{min}^{-1}\right)$

$R \quad$ universal gas constant $\left(8.314 \mathrm{~kJ} \mathrm{~mol}^{-1} \mathrm{~K}^{-1}\right)$

$t \quad$ time $(\min )$

$T \quad$ absolute temperature (K)

3 relative to thermosonication blanching

ref at the reference temperature

$84.6{ }^{\circ} \mathrm{C}$ at the reference temperature of $84.6{ }^{\circ} \mathrm{C}$

$87.5^{\circ} \mathrm{C}$ at the reference temperature of $87.5^{\circ} \mathrm{C}$

\section{Subscripts}

$0 \quad$ initial value at time equal to zero

1 relative to labile enzyme fraction

The enzymes have a region (called the substrate binding site, the active site or the catalytic site) that is complementary in size, shape and chemical nature to the substrate molecule. Today, it is recognized that the active site, rather than a rigid geometrical cavity, it is a very specific and precise spatial arrangement of amino acid residues $\mathrm{R}$-groups that can interact with complementary groups on the substrate (Segel, 1993).

Three main processes have been considered to be involved in the inactivation of peroxidase; (1) dissociation of prosthetic (heme) group from the haloenzyme (active enzyme system); (2) conformation change in the apoenzyme (protein part of the enzyme); and/or (3) modification or degradation of the prosthetic group (Lemos, Oliveira, \& Saraiva, 2000).

Application of heat treatment is the most utilized method for stabilising foods, because of its capacity to destroy microorganisms and inactivate enzymes. However, since heat can impair, as well, many organoleptic properties of foods and reduce the contents or bioavailability of some nutrients, there is a growing interest in searching for new technologies able to reduce the intensity of the heat treatments needed for food preservation (López et al., 1994).

Thermal inactivation kinetics studies in POD, in the range of $70-100{ }^{\circ} \mathrm{C}$, have clearly shown biphasic curves, which might be due to the presence of isoenzymes with different thermal stabilities (Forsyth, Apenten, \& Robinson, 1999; Ganthavorn, Nagel, \& Powers, 1991; Günes \& Bayindirli, 1993; Powers, Costello, \& Leung, 1984; Sarikaya \& Özilgen, 1991; Wang \& Luh, 1983). An inactivation biphasic model was proposed by Ling and Lund (1978) to describe the thermal inactivation kinetics of an enzyme system formed by a heat-labile fraction and a heat-resistant fraction, both with first-order inactivation kinetics. Later, Morales-Blancas, Chandia, and Cisneros-Zevallos (2002) modelled also peroxidase behaviour in broccoli, green asparagus and carrots (Table 1).

In the food industry, the use of ultrasounds has been a subject of research and development for many years and, as is the case of other areas, the sound ranges employed can be divided basically into; (1) high frequency, low energy, diagnostic ultrasound in the $\mathrm{MHz}$ range; and (2) low frequency and high energy, power ultrasound in the $\mathrm{kHz}$ range (Mason, Paniwnyk, \& Lorimer, 1996). Ultrasounds consist of longitudinal waves, i.e. periodical alterations of local pressure at a frequency range of $16 \mathrm{kHz}$ to $1 \mathrm{GHz}$. The propagation rate of ultrasounds in water is $1500 \mathrm{~m} \mathrm{~s}^{-1}$, in solid bodies about $4000 \mathrm{~m} \mathrm{~s}^{-1}$, and in water-rich biological tissues it is around $1479 \mathrm{~m} \mathrm{~s}^{-1}$. Ultrasounds can also be classified into low-intensity (LI) (frequency range of $5-10 \mathrm{MHz}$ ) and high-intensity (HI) (frequency range of 20-100 $\mathrm{kHz}$ ). LI ultrasounds are commonly used in the medical

Table 1

Published activation energies $\left(E_{\mathrm{a}}\right)$ for POD heat-labile and heat-resistant fractions in vegetables

\begin{tabular}{llcl}
\hline Product & Heat-resistant fraction & Heat-labile fraction & Reference \\
\cline { 2 - 4 } & $E_{\mathrm{a} 2}\left(\mathrm{~kJ} \mathrm{~mol}^{-1}\right)$ & $E_{\mathrm{a} 1}\left(\mathrm{~kJ} \mathrm{~mol}^{-1}\right)$ & Morales-Blancas et al. (2002) \\
\hline Broccoli & 58 & 75 & Morales-Blancas et al. (2002) \\
Asparagus (stem) & 53 & 61 & Morales-Blancas et al. (2002) \\
Carrot (cortex) & 86 & 95 & Ling and Lund (1978) \\
Horseradish & 88 & 142 & Anthon and Barrett (2002) \\
Carrot & 480 & - & Anthon and Barrett (2002) \\
Potato & 478 & - & Anthon et al. (2002) \\
Tomato (CXD 199) & 546 & - & Anthon et al. (2002) \\
Tomato (BOS 3155) & 557 & - & \\
\hline
\end{tabular}


science for diagnostic purposes and can also be used in food science to evaluate texture, composition or viscosity of foods. It uses very small power levels, typically less than $1 \mathrm{~W} \mathrm{~cm}^{-2}$ (Lee, Heinz, \& Knorr, 2003). The influence of ultrasounds on cells and tissues is caused by the appearance of local pressures and on local accelerations. According to the frequency of the ultrasound, alternating positive and negative pressures appear locally, leading to stretch or compression of the material and causing cell disrupture. Homogeneous liquids have a considerable resistance to the disruption effect (Glaser, 2001). Sonication also promotes chemical reactions involving $\mathrm{H}^{+\cdot}$ and $\mathrm{OH}^{-\cdot}$ free radicals, formed by the decomposition of water inside the oscillating bubbles. Free radicals so produced could be scavenged by some amino acid residues of the enzymes participating in structure stability, substrate binding, or catalytic functions (López et al., 1994).

The use of ultrasound in processing creates novel and interesting methodologies, which are often complementary to classical techniques. It has proved to be particularly useful in sterilisation, extraction, freezing and filtration, providing reduced processing times and increased efficiency. Current studies have identified a number of other areas, including the stimulation of living cells and enzymes, improved processing of reformed meat and grain treatment (Mason et al., 1996). The objective of this work was to study the blanching conditions of watercress (Nasturtium officinale) with a combined method of heat and ultrasound and with the findings help to design better processing conditions for a new frozen vegetable product, using watercress (Nasturtium officinale).

\section{Material and Methods}

\section{Vegetable samples}

Fresh watercress (Nasturtium officinale) was gently supplied by Vitacress, a company that grows watercress in Almancil, Algarve. The leaves were selected, washed thoroughly and analysed within $24 \mathrm{~h}$.

\section{Peroxidase determination}

Buffer and substrate preparation

Hydrogen peroxide 30\% (Panreac), guaiacol 99.5\% (BDH Chemicals Ltd.) and potassium phosphate buffer were used as a substrate solution. Potassium phosphate buffer was prepared with monopotassium phosphate (Merck) and dipotassium phosphate (Merck) in distilled water obtaining a molar concentration of $0.1 \mathrm{~mol} / \mathrm{L}$ and $\mathrm{pH}$ 6.5. The buffer solution was cooled at $4{ }^{\circ} \mathrm{C}$ until used.

\section{Enzyme extract}

Preliminary experiments were performed to determine the presence of peroxidase in watercress (Nasturtium officinale). The ratio between sample weight $(\mathrm{g})$ and the buffer solution volume $(\mathrm{mL})$ was also determined, for optimal reproducibility and linearity between enzyme concentration and observed activity.

After blanching, the leaves were mixed with cold potassium phosphate buffer in the proportion of 3:100 w/v. Each sample was homogenized in an Ultra-Turrax T25 Janke \& Kunkel for $1 \mathrm{~min}$ at $13,500 \mathrm{rpm}$ in an Erlenmeyer. The homogenates were centrifuged in a Sigma 3 K20 centrifuge with a rotor no. 12,158 at $18.000 \times g$ and $4{ }^{\circ} \mathrm{C}$ for 30 min with polypropylene tubes $(25 \mathrm{~mm} \times 92 \mathrm{~mm})$.

\section{Peroxidase assay}

Based on the method reported by Morales-Blancas et al. (2002), the peroxidase activity was measured as follows: enzyme extract $(120 \mu \mathrm{L})$ was added to $3.48 \mathrm{~mL}$ of substrate solution (prepared daily), which contained $99.8 \mathrm{~mL}$ of $0.1 \mathrm{M}$ potassium phosphate buffer (pH 6.5), $0.1 \mathrm{~mL}$ of $99.5 \%$ guaiacol and $0.1 \mathrm{~mL}$ of $30 \%$ hydrogen peroxide. The increase in absorbance at $470 \mathrm{~nm}$ was recorded at $6 \mathrm{~s}$ intervals using $10 \mathrm{~mm}$ path-length glass cuvettes (Amersham Biosciences) and an UV/vis, Hitachi U-2000 spectrophotometer. The rate of increase of absorbance was converted to a rate of conversion of substrate and product, using the observation that the absorbance constant for tetraguaiacol at $470 \mathrm{~nm}$ is $26.6 \mathrm{mM}^{-1} \mathrm{~cm}^{-1}$. Enzyme specific activity was expressed as $\mu \mathrm{molmin}{ }^{-1} \mathrm{mg}$ protein ${ }^{-1}$. Reaction rate was calculated from the slope of the initial linear portion of a plot of absorbance vs. time. The peroxidase specific activity was measured in the blanched and fresh watercress (Nasturtium officinale), as well as in the blanching water to verify leaching effect.

\section{Protein determination}

Protein content was determined by Lowry's method (Lowry, Rosenbrough, Farr, \& Randall, 1951) and by measuring absorbance at $540 \mathrm{~nm}$. Bovine serum albumin (BSA) (Fluka) was used as standard.

\section{Thermal inactivation experiments}

Each sample of watercress (Nasturtium officinale) $(3 \mathrm{~g})$ was blanched in individual conical flasks, with $100 \mathrm{~mL}$ of distilled water, in a water bath Grant W14. Temperatures ranging from 40 to $92.5^{\circ} \mathrm{C}$, with different times of exposure, were investigated. To stop the blanching treatments, in the shortest period of time possible, the flasks were immediately transferred to an iced water bath in order to cool down the samples rapidly to $2{ }^{\circ} \mathrm{C}$. The temperature was monitored with a digital 
thermometer (Ellab ctd 87) and a thermocouple (1.2 $\mathrm{mm}$ needle dia; constantan-type T).

\section{Thermosonication inactivation experiments}

A second approach was the combination of heat/ ultrasound applied to the watercress (Nasturtium officinale) for the same range of temperatures. The samples were processed with an ultrasound horn (Coleparmer $\mathrm{V} 1 \mathrm{~A} ; 13 \mathrm{~mm}$ dia) at $20 \mathrm{kHz}$ and an ultrasound generator (Coleparmer 4710 Series) radiating $50 \%$ of power.

\section{Kinetics modelling}

In order to evaluate the influence of ultrasounds on the inactivation of peroxidase, the traditional blanching process by heat was firstly modelled.

Heat blanching showed a biphasic inactivation firstorder behaviour, formed by a heat-labile isoenzyme fraction and a heat-resistant isoenzyme fraction (Eq. (1)).

$C=C_{01} \mathrm{e}^{-k_{1} t}+C_{02} \mathrm{e}^{-k_{2} t}$

For both isoenzyme fractions, it was assumed that the first-order rate constants, $k_{1}$ and $k_{2}$, dependence on temperature followed the Arrhenius law:

$k_{1}=k_{1 \mathrm{ref}} \mathrm{e}^{\left[-\frac{E_{\mathrm{al}}}{R}\left(\frac{1}{T}-\frac{1}{T_{\text {ref }}}\right)\right]}$

$k_{2}=k_{2 \mathrm{ref}} \mathrm{e}^{\left[-\frac{E_{\mathrm{a} 2}}{R}\left(\frac{1}{T}-\frac{1}{T_{\mathrm{ref}}}\right)\right]}$

By substitution, Eq. (1) can be expressed as

$$
\begin{aligned}
C= & C_{01} \mathrm{e}\left\{-k_{1 \text { ref }} \mathrm{e}^{\left[-\frac{E_{21}}{R}\left(\frac{1}{T}-\frac{1}{T_{\text {ref }}}\right)\right]} t\right\} \\
& +C_{02} \mathrm{e}\left\{-k_{2 \text { ref }} \mathrm{e}^{\left[-\frac{E_{\text {a2 }}}{R}\left(\frac{1}{T}-\frac{1}{T_{\text {ref }}}\right)\right]} t\right\}
\end{aligned}
$$

$T_{\text {ref }}$ (reference temperature) was considered to be the average temperature of the experiments $\left(T_{\text {ref }}=\right.$ $84.6^{\circ} \mathrm{C}$-heat blanching).

In the thermosonication blanching process an inactivation first-order model was verified (Eq. (5)).

$C=C_{03} \mathrm{e}\left\{-k_{3 \mathrm{ref}} \mathrm{e}^{\left[-\frac{E_{\mathrm{a3}}}{R}\left(\frac{1}{T}-\frac{1}{T_{\text {ref }}}\right)\right]} t\right\}$

( $T_{\text {ref }}=87.5^{\circ} \mathrm{C}$ - thermosonication blanching).

Experimental data points were normalized, dividing the specific activities by the initial value at time zero, before any processing. A one step non-linear regression was performed to all the experimental relative specific activities (Arabshahi \& Lund, 1985) that presented inactivation, using the statistical software STATA version 6.0 (Stata Corp, 1999).

\section{Results and Discussion}

Fresh watercress (Nasturtium officinale) showed an initial specific activity $\left(C_{0}\right)$ of $0.02 \pm 0.002 \mu \mathrm{mol}$ $\min ^{-1} \mathrm{mg}$ protein ${ }^{-1}$.

The model in Eq. (4) was used for heat blanching processes, and Eq. (5) for thermosonication blanching processes. In what concerns the blanching water, no enzyme activity was detected. Therefore, no significant leaching occurred.

In the heat blanching study, the reduction of peroxidase specific activity was more evident for higher temperatures and during the first $10 \mathrm{~s}$, due to the presence of the heat-labile fraction, which is inactivated faster at high temperatures. The biphasic first-order model fits well the experimental data for the heat blanching processes and the kinetic parameters determined were significant $(\alpha=0.05)$. The rate constants, $k_{1}$ and $k_{2}$, dependence on the temperature followed the Arrhenius behaviour (Eqs. (2) and (3)). The activation energies, the rates of the reaction at the reference temperature, and the initial relative specific activities, were estimated for both the heat-labile and heat-resistant fractions, and were, respectively, $E_{\mathrm{a} 1}=421 \pm 115 \mathrm{~kJ} \mathrm{~mol}^{-1}, k_{1_{84.6}{ }^{\circ} \mathrm{C}}=$ $18 \pm 14 \mathrm{~min}^{-1}$ and $C_{01}=0.5 \pm 0.08 \mu \mathrm{mol} \mathrm{min}^{-1} \mathrm{mg}$ protein $^{-1}$ and $E_{\mathrm{a} 2}=352 \pm 81 \mathrm{~kJ} \mathrm{~mol}^{-1}, \quad k_{24.6^{\circ} \mathrm{C}}=0.24 \pm$ $0.14 \mathrm{~min}^{-1}$ and $C_{02}=0.5 \pm 0.06 \mu \mathrm{molmin}^{-1} \mathrm{mg}$ pro$\operatorname{tein}^{-1}$ (see Table 2). Our results agree with those of Morales-Blancas et al. (2002) and Ling and Lund (1978) in studies on the thermal inactivation kinetics of peroxidase, in which the values of $E_{\mathrm{a}}$ for the heatlabile fraction are higher than the values of $E_{\mathrm{a}}$ for the heat-resistant fraction, for temperatures ranging from 70 to $96{ }^{\circ} \mathrm{C}$ (Table 1). Although their activation energies are much lower than ours, higher activation energies for the heat-resistant fraction, that are in our range of values, were reported for POD from potato $\left(478 \mathrm{~kJ} \mathrm{~mol}^{-1}\right)$ and carrot $\left(480 \mathrm{~kJ} \mathrm{~mol}^{-1}\right.$ ) by Anthon and Barrett (2002), and from two tomato cultivars $\left(546 \mathrm{~kJ} \mathrm{~mol}^{-1}\right.$; $557 \mathrm{~kJ} \mathrm{~mol}^{-1}$ ) by Anthon, Sekine, Watanabe, and Barrett (2002) (Table 1).

The application of thermosonication showed an increase on the enzyme activity in the temperature range

Table 2

Kinetic parameters of thermal inactivation of peroxidase in watercress (Nasturtium officinale) (heat blanching process), for heat-labile (1) and heat-resistant (2) isoenzyme fractions

\begin{tabular}{ll}
\hline$C_{01}\left(\mu \mathrm{molmin}^{-1} \mathrm{mg}\right.$ protein $\left.^{-1}\right)$ & $0.5 \pm 0.08$ \\
$k_{1_{84.6}{ }^{\circ} \mathrm{C}}\left(\mathrm{min}^{-1}\right)$ & $18 \pm 14$ \\
$E_{\mathrm{a} 1}\left(\mathrm{~kJ} \mathrm{~mol}^{-1}\right)$ & $421 \pm 115$ \\
$C_{02}\left(\mu \mathrm{mol} \mathrm{min}^{-1} \mathrm{mg}\right.$ protein $\left.^{-1}\right)$ & $0.5 \pm 0.06$ \\
$k_{2_{84.6}{ }^{\circ} \mathrm{C}}\left(\mathrm{min}^{-1}\right)$ & $0.24 \pm 0.14$ \\
$E_{\mathrm{a} 2}\left(\mathrm{~kJ} \mathrm{~mol}^{-1}\right)$ & $352 \pm 81$ \\
$R^{2}$ & 0.94 \\
Adjusted $R^{2}$ & 0.93 \\
\hline
\end{tabular}


of $40-80{ }^{\circ} \mathrm{C}$. This result was not expected, since at low temperatures instead of promoting the inactivation or maintaining the activity, the combined treatment had an antagonistic effect (Fig. 1). The increase of the enzyme activity with ultrasound, at low temperatures, could be related with the change of conformation of the enzyme to a higher enzyme-substrate interaction, and consequently to an optimal stage of consumption of the substrate. For higher temperatures, the combined treatment had a synergistic effect, since the enzyme activity decreased at a higher rate when compared to the traditional heat treatment (Fig. 2). The reduction of specific activity is related to the conformation changes in the tertiary structure, as in the active site three-dimensional structure affecting the enzyme-substrate interaction.
Thus, the modelling of the enzyme inactivation with thermosonication was important in this study, once it is in favour of less severe heat blanching conditions. Therefore, an inactivation first-order model was applied, since the enzyme labile fraction was inactivated so quickly that it could not be detected. The experimental data fitted well a first-order model $\left(R^{2}=0.97\right)$ and the kinetic parameters estimated by the model were significant $(\alpha=0.05)$. The activation energy, the rate of reaction at a reference temperature of $87.5^{\circ} \mathrm{C}$, and the initial relative specific activity were estimated and were, respectively, $E_{\mathrm{a} 3}=496 \pm 65 \mathrm{~kJ} \mathrm{~mol}^{-1}, \quad k_{387 .{ }^{\circ} \mathrm{C}}=10 \pm 2 \mathrm{~min}^{-1} \quad$ and $C_{03}=1 \pm 0.05 \mu \mathrm{mol} \mathrm{min}^{-1} \mathrm{mg} \mathrm{protein}^{-1}$ (Table 3).

Fig. 3 shows the residuals plot (with no tendency), meaning that the models are adequate to the experimental data. $40^{\circ} \mathrm{C}$

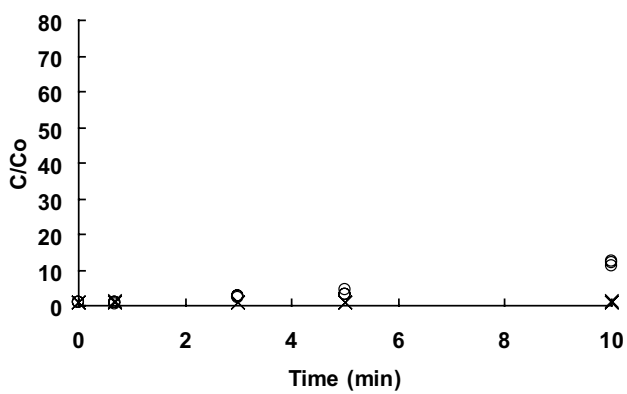

$65^{\circ} \mathrm{C}$

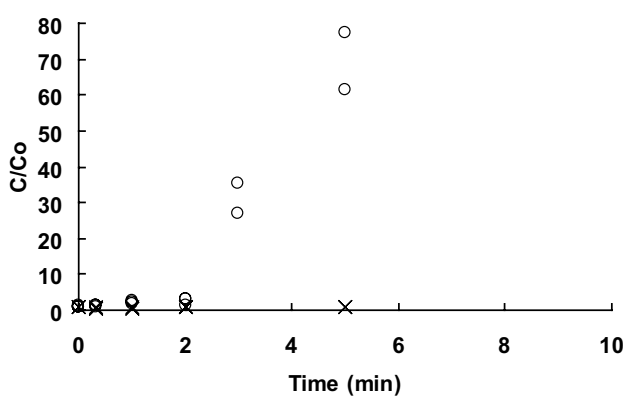

$50^{\circ} \mathrm{C}$

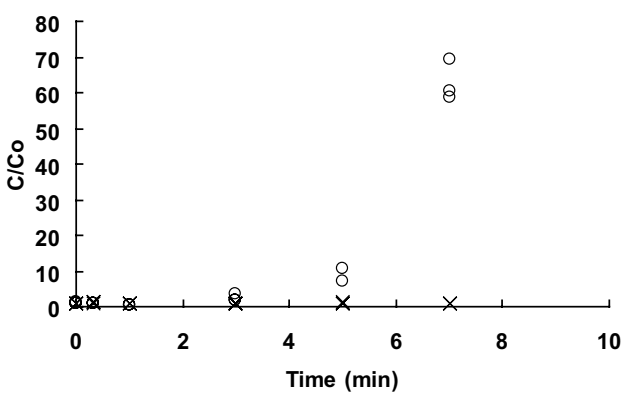

$75^{\circ} \mathrm{C}$

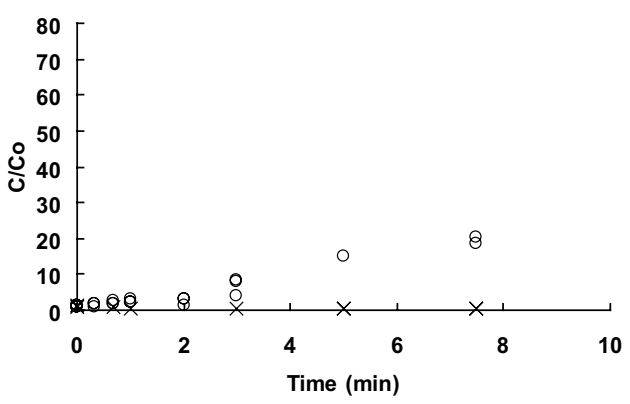

$80^{\circ} \mathrm{C}$

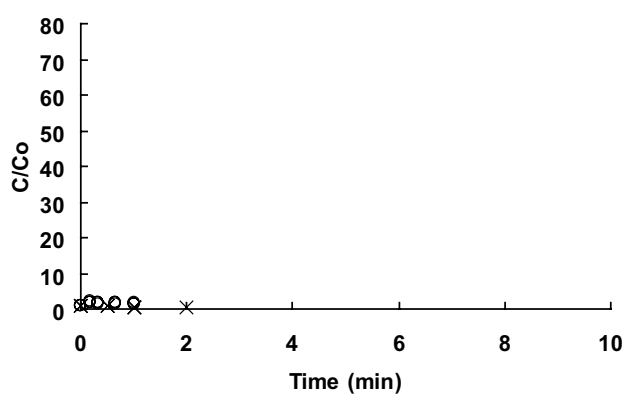

Fig. 1. Effect of temperature, ultrasound and time on peroxidase specific activity in watercress (Nasturtium officinale) in the temperature range of $40-80^{\circ} \mathrm{C}:(\times)$ experimental values of POD specific activity with heat blanching processes; (o) experimental values of POD specific activity with thermosonication blanching processes. 

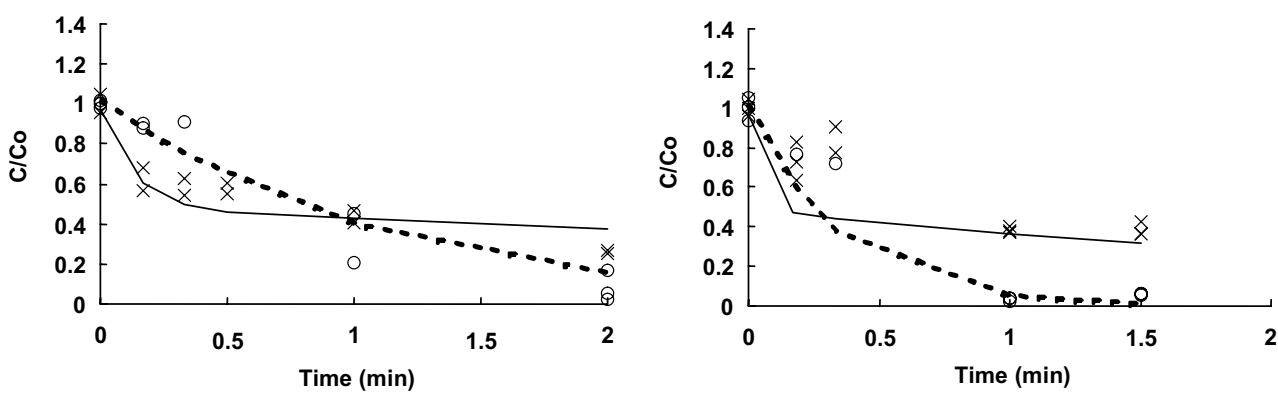

$87.5^{\circ} \mathrm{C}$
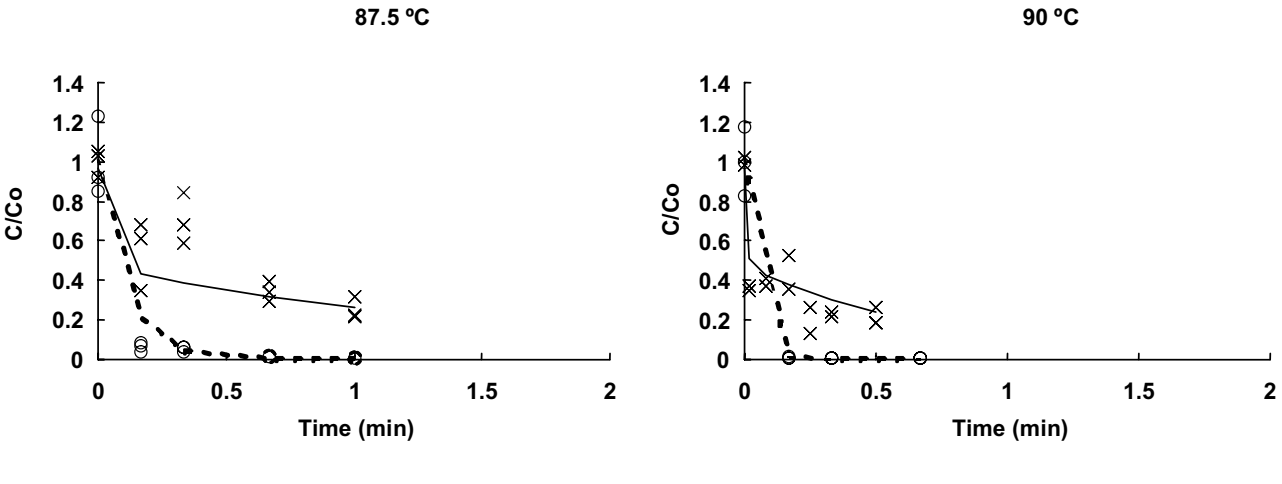

$92.5^{\circ} \mathrm{C}$

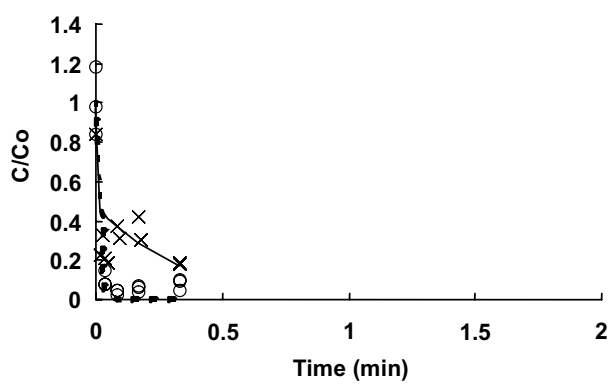

Fig. 2. Effect of temperature, ultrasound and time on peroxidase relative specific activity in watercress (Nasturtium officinale) in temperature range of 82.5-92.5 ${ }^{\circ} \mathrm{C}:(\times)$ experimental values of POD relative specific activity with heat blanching processes; $(-)$ model predicted values for heat blanching processes; ( $)$ experimental values of POD relative specific activity with thermosonication blanching processes; (- - -) model predicted values for thermosonication blanching processes.

Table 3

Kinetic parameters of thermosonication inactivation of peroxidase in watercress (Nasturtium officinale)

\begin{tabular}{ll}
\hline$C_{03}\left(\mu \mathrm{molmin}^{-1} \mathrm{mg}\right.$ protein $\left.^{-1}\right)$ & $1 \pm 0.05$ \\
$k_{37.5{ }^{\circ} \mathrm{C}}\left(\mathrm{min}^{-1}\right)$ & $10 \pm 2$ \\
$E_{\mathrm{a} 3}\left(\mathrm{~kJ} \mathrm{~mol}^{-1}\right)$ & $496 \pm 65$ \\
$R^{2}$ & 0.97 \\
Adjusted $R^{2}$ & 0.97 \\
\hline
\end{tabular}

\section{Conclusions}

The peroxidase enzyme system, found in watercress (Nasturtium officinale), is formed by a heat-labile fraction and a heat-resistant fraction. The biphasic firstorder model fits well the experimental data of the heat blanching processes. For the thermosonication blanching processes, a first-order model fits better the experimental data, as the enzyme inactivation was obtained only by the heat-resistant fraction. With these models and the kinetic parameters determined, it is possible to predict the peroxidase specific activity as well as temperature and blanching process time.

The application of thermosonication, for temperatures above $85^{\circ} \mathrm{C}$ and for the same blanching times, led to higher enzyme inactivation when compared with the heat blanching processes. These results allow the application of shorter blanching times at this range of temperatures, leading to a product with a higher quality, or minimized processing. Thus, the thermosonication treatments can be a good alternative to the traditional heat blanching processes. 

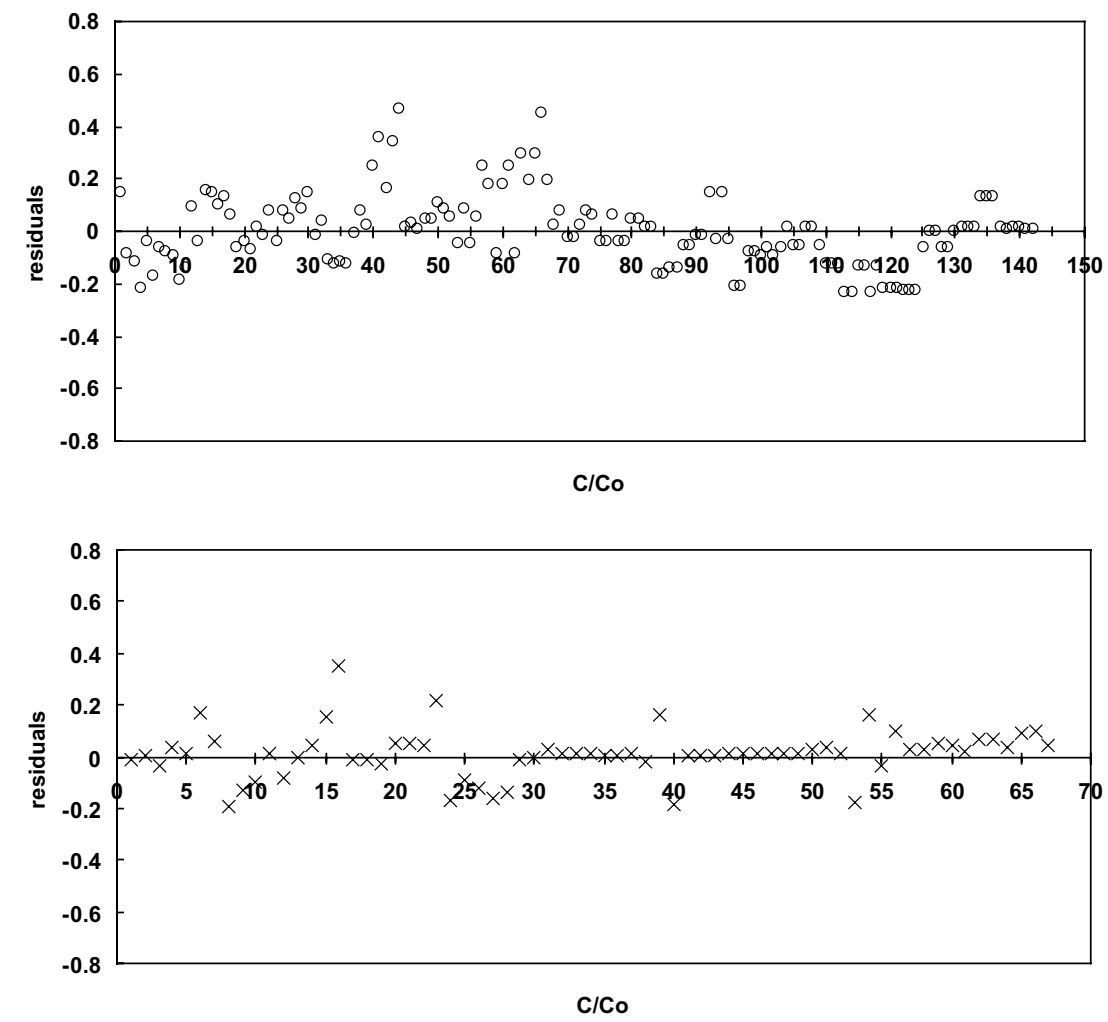

Fig. 3. Plot of residuals for $C / C_{\mathrm{o}}$ experimental data against the predicted values of the model: $(\times)$ heat blanching processes; (o) thermosonication blanching processes.

This study will help to design the watercress (Nasturtium officinale) blanching conditions for the freezing process with heat and thermosonication. Therefore, it will be possible to produce a new and healthy frozen product with minimum colour or flavour changes along the frozen shelf life.

\section{Acknowledgments}

The author Rui M.S. Cruz gratefully acknowledges his Ph.D. grant SFRH/BD/9172/2002 to Fundação para a Ciência e a Tecnologia (FCT) from Ministério da Ciência e do Ensino Superior. The authors thank the Vitacress Company for supplying the raw watercress (Nasturtium officinale).

\section{References}

Anthon, G. E., \& Barrett, D. M. (2002). Kinetic parameters for the thermal inactivation of quality-related enzymes in carrots and potatoes. Journal of Agricultural and Food Chemistry, 50, 4119-4125.

Anthon, G. E., Sekine, Y., Watanabe, N., \& Barrett, D. M. (2002). Thermal inactivation of pectin methylesterase, polygalacturonase, and peroxidase in tomato juice. Journal of Agricultural and Food Chemistry, 50, 6153-6159.
Arabshahi, A., \& Lund, D. B. (1985). Considerations in calculating kinetics parameters from experimental data. Journal of Food Processing and Engineering, 7, 239-251.

Barret, D. M., \& Theerakulkait, C. (1995). Quality indicators in blanched, frozen, stored vegetables. Food Technology, 49(1), $62-65$.

Forsyth, J. L., Apenten, R. K. O., \& Robinson, D. S. (1999). The thermostability of purified isoperoxides from Brassica oleracea var. gemmifera. Journal of Food Chemistry, 65(1), 99-109.

Ganthavorn, C., Nagel, C. W., \& Powers, J. R. (1991). Thermal inactivation of asparagus lipoxygenase and peroxidase. Journal of Food Science, 56(1), 47-49.

Glaser, R. (2001). Physical factors of the environment. In Biophysics (pp. 254-255). Berlin: Springer.

Günes, B., \& Bayindirli, A. (1993). Peroxidase and lipoxygenase inactivation during blanching of green beans, green peas and carrots. Lebensm-Wiss u-Technologie, 26(5), 406-410.

Lee, D. U., Heinz, V., \& Knorr, D. (2003). Effects of combination treatments of nisin and high-intensity ultrasound with pressure on the microbial inactivation in liquid whole egg. Innovative Food Science and Emerging Technologies, 4, 387-393.

Lemos, M. A., Oliveira, J. C., \& Saraiva, J. A. (2000). Influence of pH on the thermal inactivation kinetics of horseradish peroxidase in aqueous solution. Lebensm-Wiss $u$-Technologie, 33, 362-368.

Ling, A. C., \& Lund, D. B. (1978). Determining kinetic parameters for thermal inactivation of heat-resistant and heat-labile isozymes from thermal destruction curves. Journal of Food Science, 43, $1307-1310$.

López, P., Sala, F. J., Fuente, J. L., Condón, S., Raso, J., \& Burgos, J. (1994). Inactivation of peroxidase, lipoxygenase, and polyphenol oxidase by manothermosonication. Journal of Agricultural and Food Chemistry, 42, 252-256. 
Lowry, O. H., Rosenbrough, N. J., Farr, A. L., \& Randall, R. J. (1951). Protein measurement with folin phenol reagent. Journal of Biology and Chemistry, 193, 265-270.

Mason, T. J., Paniwnyk, L., \& Lorimer, J. P. (1996). The uses of ultrasound in food technology. Ultrasonics Sonochemistry, 3, 253-260.

Morales-Blancas, E. F., Chandia, V. E., \& Cisneros-Zevallos, L. (2002). Thermal inactivation kinetics of peroxidase and lipoxygenase from broccoli, green asparagus and carrots. Journal of Food Science, 67(1), 146-154.

Powers, J. R., Costello, M. J., \& Leung, H. K. (1984). Peroxidase fraction from asparagus of varying heat stabilities. Journal of Food Science, 49(6), 1618-1619.
Sarikaya, A., \& Özilgen, M. (1991). Kinetics of peroxidase inactivation during thermal processing of whole potatoes. Lebensm-Wiss uTechnologie, 24(2), 159-163.

Segel, I. H. (1993). Enzymes as biological catalysts. In Enzyme kinetics (pp. 7-14). USA: John Wiley and Sons.

Stata Corporation. (1999). Stata statistical software: Release 6.0 college station.

Wang, Z., \& Luh, B. S. (1983). Characterisation of soluble and bound peroxidases in green asparagus. Journal of Food Science, 48(5), $1412-1417,1421$.

Williams, D. C., Lim, M. H., Chen, A. O., Pangborn, R. M., \& Whitaker, J. R. (1986). Blanching of vegetables for freezing - Which indicator enzyme to choose? Food Technology, 40(6), 130-139. 